Edward Breza

Uniwersytet Gdański

\title{
NIEKTÓRE RZADSZE IMIONA MĘSKIE (V) ${ }^{1}$
}

\section{Labir}

SIW podaje 1 mężczyznę o im. Labir, poza tym nienotowane w wyzyskiwanych przeze mnie źródłach i opracowaniach.

Kojarzyć się może z niem. Laub 'liść' i ew. niem. Bier 'piwo' (por. SEMot V, s. 154).

\section{Labrini}

SIW podaje 2 mężczyzn o im. Labrini: po $1 \mathrm{w}$ woj. krakowskim i słupskim. Nie notuje SI ani wyzyskiwane przeze mnie źródła i opracowania.

Od formy dopełniaczowej łacińskiej nazwy mieszkańca Labrinus miejscowości Laab w Bawarii i Austrii bądź Laaber, Laber w Bawarii (DF, s. 408).

\section{Lach}

SIW podaje 1 mężczyznę o im. Lach w woj. krośnieńskim. SI nie notuje.

SSNO III, s. 220, VII, s. 127 utrwala imię Lach od r. 1428 z Mazowsza, z r. 1437 z Kresów Południowo-Wschodnich. SEMot IV, s. 7 wywodzi od n. etnicznej Lach 'Polak'; SEMot VII, s. 348 odnosi do im. Lenart, czego jednak w SEMot II, s. 77 nie znajduję. Moim zdaniem możliwe także jako hipokorystyk Łach od Łazarz z zamianą $E>L$., por. 4721 osób o nazwisku Łach w SNW.

1 Poprzednie części cyklu Niektóre rzadsze imiona męskie zostały opublikowane w „Rozprawach Komisji Językowej Łódzkiego Towarzystwa Naukowego", których wieloletnim redaktorem był śp. prof. dr hab. Sławomir Gala: t. L, 2005, s. 5-20 (imiona: Abelard; Adonis i podobne; Agenor; Ajaks, Ajas; Aladyn i podobne; Alary; Bodo; Borgiasz, Borgia; Burchart, Burghard, Burhard i podobne; Brutus; Cels, Celsjusz; Cyryk; Dydym, Dydymus; Gebhard; Gentram; Hannibal; Job, Hiob; Kewin, Kevin; Menelaus; Pimen, Pimon; Platon, Platonida; Santiago; Tryfon, Trifon i podobne); t. LIII, 2008, s. 17-44; t. LVI, 2011, s. 5-45; t. LX, 2014, s. 15-49. 


\section{Laco}

SIW podaje 1 mężczyznę o im. Laco w woj. gdańskim. SI nie notuje, niepotwierdzone w staropolszczyźnie (SSNO).

Go, s. 398 odsyła do Władysław, realizowanego w łacinie, niemczyźnie i w wielu innych językach (zob. SI, s. 281-281) jako Ladislaus, a od tej postaci powstało zdrobnione imię Latz, pisane po polsku Lac, przez analogię do imion Bruno, Hugo też Laco (por. też DF, s. 413 i hasło Ladislav).

\section{Lada, Ladie}

SIW podaje po 1 kobiecie o im. Lada w woj. bialskopodlaskim i Ladie w woj. katowickim; SI nie notuje, niepoświadczone w staropolszczyźnie (SSNO).

Sa to formy hipokorystyczne od im. Władystawa.

\section{Ladislao, Ladislav, Ladislaw, Ladislaw}

SIW podaje 1 mężczyznę o im. Ladislao w woj. łódzkim; 6 - Ladislav: 2 w woj. warszawskim, po $1 \mathrm{w}$ bielskim, gdańskim, łódzkim i olsztyńskim; 3 -Ladisław: po $1 \mathrm{w}$ woj. kieleckim, legnickim i zamojskim; 2 -Ladisława: po $1 \mathrm{w}$ woj. kieleckim i włocławskim; 3 -Ladysław: po 1 w woj. łódzkim, szczecińskim i toruńskim.

Są to wszystko warianty fonetyczno-graficzne im. Władysław: SI, s. 281-282 podaje Ladislao w jęz. hiszp. i wł.; Ladislav w cz.; Ladislaw w górnołuż., Ladisław w dolnołuż. Imię Władysław według SIW nosi 280142 obywateli polskich. Warianty wyżej podane odnoszą się najprawdopodobniej do cudzoziemców (SIW nie podaje narodowości). Tu należy zapewne także Lodysław - $1 \mathrm{w}$ woj. piotrkowskim.

\section{Ladrencjusz}

SIW podaje 1 mężczyznę o im. Ladrencjusz w woj. częstochowskim, SI nie notuje, niepoświadczone w staropolszczyźnie (SSNO), nienotowane wśród przydomków łacińskich (cognomina) IC.

Struktura przypominający z pochodzenia łac. imiona typu Laktancjusz od lacto, -are, -avi, -atum 'podawać mleko, karmić piersią', Wenancjusz od venor, -ari, -atus sum 'polować' (por. IC, s. 45) o suf. -ent-, zatem możliwa hybryda od niem. Lader od ap. Lader : laden 'ładować' (DF, s. 408).

\section{Lael}

SIW podaje 1 mężczyznę o im. Lael w woj. rzeszowskim. SI nie notuje, niepotwierdzone w staropolszczyźnie (SSNO).

Rdzeń odnieść można do łac. przydomka (cognomen) Laelianus (IC, s. 148), notowanego także wśród chrześcijan, utworzonego za pomocą przyrostka -anus, nazywającego wyzwoleńców lub adoptowanych od n. rzymskiego rodu plebejskiego Laelii, którzy znani są m.in. z pism Cycerona (Kr, s. 470), a dodać można, 
że imiona od rodów rzymskich są częstym zjawiskiem w kulturze europejskiej, por. np. Emil od rodu patrycjuszowskiego Aemilii od aemulor, -ari, -atus sum 'współzawodniczyć, rywalizować' (Kr, s. 25), z czego polskie emulacja 'współzawodnictwo'; Klaudiusz od Claudii, a to od przymiotnika claudus, -a, -um 'kulawy'; por. film $J a$, Klaudiusz, gdzie bohater kuleje, i łacińskie przysłowie „Omnis comparatio claudicat” 'Wszelkie porównanie kuleje'.

\section{Lai, Laia, Lajas}

SIW podaje po 1 mężczyźnie o im. Lai w woj. szczecińskim, 1 - Laia w woj. wałbrzyskim i 1 -Lajas w woj. katowickim, SI nie notuje.

SSNO III 221 poświadcza n. os. Laj z r. 1414 u ziemianina ciechanowskiego (terrigena Chechonoviemsis) i z r. 1427 z kresów wschodnich, odniesione przez SEMot I, s. 42 do rzeczownika lej 'naczynie w kształcie stożka' i 'opój', a SEMot V, s. 154 traktuje jako niem. nazwę wieloznaczną lub, jak niektórzy chca, wielomotywacyjną. Wariant Laia powstał w wyniku polszczenia przez dodanie - $a$ lub wskutek derywacji fleksyjnej: syn Laja, zatem Laja, a Lajas przy użyciu formantu -as; 1 kobieta Laja w woj. wałbrzyskim.

\section{Laima, Laimis, Laimonis}

SIW podaje 3 mężczyzn o im. Laima w woj. suwalskim; 1 Laimis w woj. suwalskim; 1 Laimonis w woj. olsztyńskim, SI nie notuje, niepotwierdzone w staropolszczyźnie (SSNO). Prawdopodobnie litewskiego pochodzenia.

\section{Lajb, Leib, Lejb, Lejbu}

SIW podaje 4 mężczyzn o im. Lajb: $2 \mathrm{w}$ woj. łódzkim, po $1 \mathrm{w}$ olsztyńskim i wałbrzyskim; 7-Lejb: $6 \mathrm{w}$ woj. wałbrzyskim, $1 \mathrm{w}$ katowickim; 23 -Lejb: po $6 \mathrm{w}$ woj. legnickim i wałbrzyskim, 3 we wrocławskim, $2 \mathrm{w}$ warszawskim, po $1 \mathrm{w}$ białostockim, opolskim i szczecińskim; 3 - Lejbu: po $1 \mathrm{w}$ woj. częstochowskim, łódzkim i szczecińskim; SI nie notuje, w staropolszczyźnie (SSNO III, s. 221) notowane jako Lajb (literalnie Layp) w Wielkopolsce, w Kościanie w r. 1494 i odniesione przez SEMot V, s. 165 do staro-wysoko-niem. podstawy lut 'sławny'; wariant Leibu dla mnie zagadkowy.

Do omawianej podstawy odnieść trzeba najprawdopodobniej imię Lejf u 1 mężczyzny w woj. łódzkim. Dziś na pewno reinterpretowane z niem. podstawą Leib 'ciało'.

\section{Lajos, Lajosz}

SIW podaje 12 mężczyzn o im. Lajos: po 2 w woj. częstochowskim, krakowskim i warszawskim, po $1 \mathrm{w}$ gdańskim, konińskim, leszczyńskim, wałbrzyskim i włocławskim; w SI 174 figuruje jako węgierski odpowiednik im. Ludwik; tak też w opracowaniach popularnych, np. KVNB, s. 71, 73; Knap, s. 116, 122. 


\section{Lajzer, Lajzor i podobne}

SIW podaje po 1 mężczyźnie w woj. łódzkim o im. Lajzer i Lajzor, SI nie notuje, niepoświadczone w tej postaci w staropolszczyźnie (SSNO).

Znam z własnej wsi Kalisz, w pow. Kościerzyna przezwisko Lajzer na mieszkańca noszącego oficjalne imię Eazarz < hebr. Eleazar 'Bóg udzielił pomocy; Bóg wspomógł' (BNOT, s. 106, 178), które z przypowieści o bogaczu i Łazarzu (Łk 16, 19-31) skojarzone zostało z biedakiem, łazega, szukającym pożywienia i schronienia, a więc czasownikiem łazić, por. łazarz 'żebrak, nędzarz' (Sych III, s. 12). Na obcokrajowca wskazywać może imię Lasar 'Łazarz' u 1 mężczyzny w woj. wrocławskim, por. w SI Lazar m.in. w blg., cz., mac., węg. i in., zapisane przez $s$, które interwokalicznie wymawiane bywa w wielu językach, np. niem., jako $z$.

\section{Lalek}

SIW podaje 1 mężczyznę o im. Lalek w woj. wrocławskim, SI nie notuje, SSNO III, s. 222 podaje imię Lalek z r. 1204 ze Śląska, które SEMot I, s. 140 odnosi do ap. lala i z uwaga, udokumentowaną bibliograficznie, prof. J. Matuszewskiego, że to Latek, a - moim zdaniem - myśleć można także o im. Eulaliusz [zob. Breza, 2014, s. 288].

\section{Lam, Lama}

SIW podaje 1 mężczyznę o im. Lam w woj. szczecińskim i 1 kobietę o im. Lama w woj. warszawskim. SI nie notuje, niepoświadczone w materiale staropolskim (SSNO); łatwo odnieść je do początkowej sylaby im. Lambert, pochodnej od staro-wysoko-niem. lant (KVNB, s. 71) = nowo-wysoko-niem. Land 'ląd, ziemia'. Por. Lambert.

\section{Lambert, Lamberta, Lamberto, Lambrijan, Lambrini, Lambro, Lambros, Lambryni, Lampert}

SIW podaje 63 mężczyzn o im. Lambert rozmieszczonych w całej Polsce, najwięcej - 7 w woj. warszawskim; w wersji hiszp., port. i wł. 8 - Lamberta: po $1 \mathrm{w}$ woj. kieleckim, legnickim, olsztyńskim, poznańskim, szczecińskim, tarnobrzeskim, warszawskim i zielonogórskim; Lamberto w woj. zielonogórskim, po 1 -Lambrijan w woj. warszawskim, Lambrini w wałbrzyskim, Lambro w jeleniogórskim; 20 -Lambros: $6 \mathrm{w}$ woj. warszawskim, $4 \mathrm{w}$ szczecińskim, po $2 \mathrm{w}$ jeleniogórskim i wrocławskim; 2 -Lambryni: po $1 \mathrm{w}$ woj. jeleniogórskim i szczecińskim; 1 - Lampert w woj. katowickim.

Imię dwuczłonowe: w I członie występuje staro-wysoko-niem. lant (KVNB, s. 71) = nowo-wysoko-niem. Land 'ląd, ziemia', por. hasło Lam; w członie II staro-wysoko-niem. beraht = nowo-wysoko-niem. berühmt 'sławny'. Od tej pod- 
stawowej wersji imienia powstały i w niemczyźnie, i w językach przejmujących (zapożyczających) różne warianty.

\section{Largus}

SIW podaje 1 mężczyznę o im. Largus w woj. warszawskim; 1 - Łargiusz w woj. katowickim (zapewne nosi je Słowianin wschodni). SI, s. 165 notuje imię Largus z takimże odpowiednikiem łacińskim Largus; ta postać występuje także w jęz. ang., cz. i niem.; Largij w jęz. błr., błg., mac., ros., słwn. i ukr.; Largas w lit., Largu w rum.; Largije u Serbów; Largo we wł., obocznie Largios, Larjos w nowogr.

Imię tkwi zapewne w nazwiskach Larga, Largin z wykładnikiem 0 (= forma z różnych względów niepewna) i 1 - Largińska w woj. warszawskim(SNW V, s. 519).

Imię pochodzi od łac. przymiotnika largus, - $a$, -um 'hojny, szczodry, obfity'. Hagiografia zna św. Largusa, męczennika z czasów Dioklecjana w r. 304, który razem z Cyriakiem poniósł śmierć męczeńską (Jougan, s. 378; KIS I, s. 564, III, s. 571).

Autorzy KIS-u wahają się, czy spolszczyć imię do postaci Largus, jak np. Cyrus, Sykstus, Tytus, formy podane w Wyk, czy Larg, jak najczęściej przez odrzucenie łac. końcówki -us przejmowaliśmy imiona i wyrazy pospolite z łaciny. Dodać tu można imię Rufus z SIW u 1 mężczyzny w woj. elbląskim. Byłbym za Largus, a więc postacią dwusylabową, jak mamy List do Tytusa, nie: Tyta, jak w niektórych dawnych tłumaczeniach Nowego Testamentu: Chrystus, choć był staropolski Kryst.

\section{Lars, Larys, Larysa i podobne}

SIW podaje 14 mężczyzn o im. Lars: $3 \mathrm{w}$ woj. katowickim, po $2 \mathrm{w}$ słupskim i wrocławskim; 1 - Larss w woj. katowickim, 1 - Larsen w woj. gdańskim; 4 - Larys: po $1 \mathrm{w}$ woj. białostockim, katowickim, kieleckim i krakowskim; 722 - Larysa, 34 - Larisa, 130 - Larysa, 32 -Laryssa; 2 - Laryssa: po $1 \mathrm{w}$ woj. suwalskim i warszawskim; 1 - Laryza w woj. tarnobrzeskim. SI, s. 165 notuje tylko formę żeńską Larysa, bez odpowiednika łacińskiego i męskiego. Larysa w jęz. błr. i ukr.; Larissa w jęz. ang., est., fin., hiszp.; Larisa w błg., cz., łot., lit., mac., u Serbów, slwn.; Larysa w ukr.; Larisza w węg.; brak we wł.; wariantywnie Larissa, Lara we fr.; Larisa, Larissa w szw.

Imieniem zająłem się dlatego, ponieważ forma męska Larys pochodzi od postaci żeńskiej Larysa, co zdarza się rzadko, regułą bowiem jest w językach (przynajmniej indoeuropejskich), że nazwy żeńskie, w tym i imiona pochodzą od męskich. Imię Larysa zaś w literaturze objaśniane jest jako forma pochodna od nazwy greckich miast Larysa, których miało być aż 8, a pisały się Larissa lub Larisa, co tłumaczy nam pisownię imienia w różnych językach $(\mathrm{Kr}, \mathrm{s} .474$; MEKSA I, s. 523), a nazwa miast od nazwy ptaka laros 'mewa', tym bardziej, że 
wyraz odnoszony bywał metonimicznie do 'chciwca' i 'głupca' (Abram III, s. 15; por. też KNI, s. 189; KVNB, s. 142 - zdaniem tych badaczy przejęte w polszczyźnie z jęz. ros.; Majtan, s. 66 wprost stwierdza, że to imię ros.; Grzenia, s. 202). Formy Lars i Larss powstały wskutek synkopy samogłoski w drugiej sylabie; Larsen to genetycznie dopełniacz lp. niem. deklinacji słabej: des Larsen > Larsen.

Lasar, Lazar, Lazaro, Lazaros, Lazar, Lazaros, Lazarz i podobne

SIW podaje 1 mężczyznę o im. Lasar w woj. wrocławskim; 5 - Lazar: $2 \mathrm{w}$ woj. warszawskim, po $1 \mathrm{w}$ katowickim, kieleckim, krakowskim; 5 -Lazaro: po $1 \mathrm{w}$ woj. białostockim, gdańskim, kieleckim, łódzkim i toruńskim; $12-L a-$ zaros: $5 \mathrm{w}$ woj. wrocławskim, po $2 \mathrm{w}$ jeleniogórskim i wałbrzyskim, po $1 \mathrm{w}$ konińskim, legnickim i słupskim; 53 - Łazarz, 2 - Łazar: po 1 w woj. katowickim i warszawskim; 1 - Łazaros w woj. wrocławskim.

Są to wszystko formy obcojęzyczne im. Eazarz: Lazar występuje w jęz. błr., błg., cz., górnołuż., mac. i ukr.; Lazaro w hiszp. i port.; Lazaros w nowogr. (zob. SI, s. 175); zapis Lasar czytany bywa Lazar pod wpływem niem.; forma Lazar czytana bywa na sposób polski zapisów obcojęzycznych Lazar.

Imię Łazarz < hebr. Eleazar 'Bóg udzielił pomocy; Bóg wspomógł' (BNOT, s. 106, 178, por. wyżej hasło Lajzer). Zapisy imienia z okresu staropolskiego zamieszcza z SSNO prof. Maria Malec (Mal III, s. 572), notowane było od r. 1414 na Kresach Południowo-Wschodnich, w Wielkopolsce w r. 1500, w Małopolsce od r. 1388, od r. 1212 na Śląsku, czyli w całej Polsce z wyjątkiem Pomorza, także w formach skróconych: Lazarek r. 1408 w Wielkopolsce; Lazarka r. 1493 tamże; Łazarzyc i Łazarzyk w Małopolsce.

\section{Laurencjusz, Laurencja i podobne}

SIW podaje 12 mężczyzn Laurencjusz, 1 - Laurenciusz w woj. piotrkowskim, 7 - Laurent, 1 -Laurentiusz w woj. opolskim, 1 -Laurenc w woj. opolskim, 2 -Laurenty: po $1 \mathrm{w}$ woj. bialskopodlaskim i krakowskim, 1 - Laury w woj. konińskim, 1 - Ławren w woj. suwalskim, 1 - Ławrenty woj. białostockim; $4-L o$ renz: $2 \mathrm{w}$ woj. opolskim, po $1 \mathrm{w}$ częstochowskim i katowickim; 3 -Lorenzo: po $1 \mathrm{w}$ woj. gdańskim, poznańskim i warszawskim (prawdopodobnie to Hiszpanie lub Włosi); 1 -Lorens w woj. słupskim; 3 -Lorenc: 2 w woj. opolskim, 1 we wrocławskim; 335 kobiet o imieniu Laurencja, 1 -Laurencia w woj. łódzkim, 1 -Laurencyna w woj. toruńskim, 1 -Laurenia w woj. gdańskim, 1 -Laurencia w woj. łódzkim; 4 -Laurenta, 2 - Laurentia: po $1 \mathrm{w}$ woj. poznańskim i włocławskim, 10 - Laurentyna; 1 - Lawrencja w woj. katowickim; 2 - Laurena: po $1 \mathrm{w}$ woj. bielskim i białostockim, 3 -Lauren, 1 -Laurence w woj. lubelskim, 1 -Laurencyna w woj. toruńskim; 1 - Lorenca w woj. nowosądeckim, 
6-Lorencja; 6 -Lorencja; 1 -Lorenta w woj. jeleniogórskim; 12 -Lorentyna; 1 - Lorentina w woj. wrocławskim.

SI, s. 275 omawia pod hasłem Wawrzyniec i wymienia Laurenty, Laurencjusz, Laurencja, Laurentyna z odpowiednikami łacińskimi Laurentius, Laurentia; Laurent w jęz. fr.; Lauris w łot.; Laurentios w nowogr.; Lorenzo w hiszp.; Lörinc w węg.; wariantywnie Lawrance, Laurence, Larrance w ang.; Laŭryn, Laŭrèncij, Lavr w błr.; Lavrentij, Lavren w błg.; Vavrinec, Laurenc, Lorenc, Laurentin w cz.; Laurits, Lars, Laurids, Laurs, Laust w dun.; Laurits, Lauri, Laarits w est.; Lauri, Lassi w fin.

W staropolszczyźnie notowane były łacińskie Laurentius i Laurencius (ok. 500 razy) w Wielkopolsce od r. 1193, od r. 1203 na Śląsku, w Małopolsce i na Pomorzu, z XIII w. na Mazowszu i na Kresach Południowo-Wschodnich; zniemczone Lorenc (ok. 20 razy) od r. 1375 w Małopolsce, na Śląsku, w Wielkopolsce, na Mazowszu i na Kresach Południowo-Wschodnich; Lorync od r. 1407 w Małopolsce, Wielkopolsce, na Mazowszu i na Kresach Południowo-Wschodnich; Loranc (2 razy) od r. 1399 w Małopolsce i na Kresach Południowo-Wschodnich; Lurync (3 razy) od r. 1453 na Kresach Południowo-Wschodnich; Larenc (2 razy) w XV w. na Kresach Południowo-Wschodnich; 1 Loryniec w r. 1398 w Wielkopolsce; w r.1478 zapisany został bez lokalizacji (Mal III, s. 339).

Podstawowe imiona Laurencjusz i żeńskie Laurencja, Lorencja to rzymskie przydomki (cognomina) Laurentius i żeński Laurentia, a pochodne Laurentianus, utworzony za pomocą przyrostka -ianus, właściwego dla tworzenia nazw wyzwoleńców i adoptowanych od Laurentius; Laurentinus i Laurentina, utworzone za pomocą patronimicznego przyrostka -inus, - $a$ od tegoż przydomka - Laurentius (IC, s. 182). Podstawą przydomków podstawowych Laurentius i Laurentia jest miasto latyńskie (według legendy pierwsza stolica Lacjum) Laurentum, położone nad Morzem Tyrreńskim, między Ostią a Lawinium (SKA, s. 258). Formy Laurentyna, Laurencyna (o obocznośći -au- / -o- zob. s.v. Loreta) kontynuują łacińskie przydomki Laurentinus, Laurentina; Lawren i Lawrenty są postaciami wschodniosłowiańskimi; Lorenz i ortograficznie spolszczone Lorenc są formami niemieckimi. O pochodzeniu (podanym wyżej) imion piszą KIS III, s. 574; KNI, s. 189-190; imieniny 3 II, 3 VI, 22 VII, 10 VIII i 5 IX (KVNB, s. 71; Kupis, s. 159; Knap, s. 117, Majtan, s. 66, najpełniej Mal III, s. 339 - tu informacja, że staroczeską forma, powstałą przez upodobnienie początkowego $L$ do $v$ w następnej sylabie, było Vavřinec, z czego polskie Wawrzyniec (zob.).

SNW podaje 1 osobę o nazwisku Lauraniec w woj. krakowskim, 4 -Laurans: $2 \mathrm{w}$ woj. krakowskim, po $1 \mathrm{w}$ warszawskim i tarnowskim, Laurant $0 ; 3$-Lauren w woj. słupskim; 27 -Laurenciak w woj. konińskim; Laurenciów 0; 3 -Laurent: 
po $1 \mathrm{w}$ woj. gdańskim, katowickim i szczecińskim; 1 - Laurenti w woj. zielonogórskim; 35 - Laurentowicz: po $7 \mathrm{w}$ woj. elbląskim, leszczyńskim i słupskim, po $3 \mathrm{w}$ gdańskim i toruńskim; 108 - Laurentowski: 55 w woj. poznańskim, 14 w leszczyńskim, 11 w zielonogórskim; Laurenz 0; Laureńciak 0; 1 - Laureńciów w woj. tarnowskim; 521 - Loranc: $412 \mathrm{w}$ woj. bielskim, 41 w katowickim, $16 \mathrm{w}$ opolskim, $9 \mathrm{w}$ konińskim; 1 - Lorancik w woj. kieleckim; 7 - Lorand w woj. gdańskim; 40 - Lorant: 24 w woj. kieleckim, 8 w krakowskim, 6 w słupskim, po $1 \mathrm{w}$ częstochowskim i radomskim; 53 -Loranta: $49 \mathrm{w}$ woj. kieleckim, $2 \mathrm{w}$ legnickim, po $1 \mathrm{w}$ katowickim i lubelskim; 557 - Loranty: $427 \mathrm{w}$ woj. kieleckim, 26 w radomskim, 23 w katowickim, 18 we wrocławskim, po 11 w gdańskim i tarnobrzeskim; 1 -Lorańc w woj. bielskim; 45 - Lorańczyk: $40 \mathrm{w}$ woj. bielskim, $4 \mathrm{w}$ katowickim, $1 \mathrm{w}$ słupskim; 2 - Loren: po $1 \mathrm{w}$ woj. warszawskim i wrocławskim; 5233 - Lorenc: 654 w woj. katowickim, 426 w krośnieńskim, $224 \mathrm{w}$ warszawskim, 221 we wrocławskim, 209 we włocławskim, 205 w poznańskim, 204 w zielonogórskim; 8 -Lorencek w woj. katowickim, 1 -Lorencen w woj. opolskim; 4-Lorencewicz w woj. warszawskim; 60 -Lorencik: $31 \mathrm{w}$ woj. kieleckim, 12 w jeleniogórskim, $5 \mathrm{w}$ wałbrzyskim, po $4 \mathrm{w}$ warszawskim i radomskim; 2 -Lorenciński w woj. lubelskim; 202 -Lorencki: 48 w woj. konińskim, 29 w częstochowskim, 20 w poznańskim, 19 w katowickim; 4 -Lorenckowski w woj. olsztyńskim; 16 - Lorencowicz: 12 w woj. lubelskim, 2 w nowosądeckim, po $1 \mathrm{w}$ warszawskim i zamojskim; 22 -Lorenczak: $13 \mathrm{w}$ woj. sieradzkim, $4 \mathrm{w}$ przemyskim, 3 w łódzkim; 14 - Lorenczewski: 9 w woj. toruńskim, 4 w ciechanowskim, 1 w toruńskim; 4 -Lorenczuk w woj. gdańskim; 81 -Lorenczyk: 74 w woj. katowickim, 7 w częstochowskim; 3 - Lorendz w woj. konińskim; 849 - Lorens: 206 w woj. katowickim, 165 w krośnieńskim, 49 w poznańskim; 458 - Lorent: $175 \mathrm{w}$ woj. warszawskim, $68 \mathrm{w}$ szczecińskim, $25 \mathrm{w}$ konińskim, 22 w łódzkim, 20 w koszalińskim; 4 - Lorenta: 3 w woj. radomskim, 1 w ostrołęckim; 267 - Lorentowicz: $180 \mathrm{w}$ woj. łódzkim, $16 \mathrm{w}$ warszawskim, $14 \mathrm{w}$ siedleckim, 13 w katowickim, 9 w elbląskim; 5 - Lorentowicz vel Lorencza w woj. sieradzkim; Lorentowska 0; 5 - Lorents: 3 w woj. tarnobrzeskim, 2 w częstochowskim; 2 -Lorentski w woj. warszawskim; 10 -Lorenty: 5 w woj. katowickim, $4 \mathrm{w}$ rzeszowskim, $1 \mathrm{w}$ tarnowskim; 112 - Lorentz: $24 \mathrm{w}$ woj. lubelskim, $21 \mathrm{w}$ warszawskim, $14 \mathrm{w}$ zamojskim; 1146 - Lorenz: $191 \mathrm{w}$ woj. katowickim, $137 \mathrm{w}$ zielonogórskim, $106 \mathrm{w}$ kaliskim, $102 \mathrm{w}$ poznańskim, $67 \mathrm{w}$ gdańskim; 1 - Lorenzo w woj. poznańskim; Loreńczak 0; 32 - Loreńczyk: 31 w woj. katowickim, $1 \mathrm{w}$ gorzowskim; 10 - Loreński: $6 \mathrm{w}$ woj. olsztyńskim, $3 \mathrm{w}$ toruńskim, $1 \mathrm{w}$ opolskim; 422 -Luranc: 292 w woj. bielskim; 35 w konińskim, 32 w katowickim, po 11 w gdańskim i krakowskim; 156 -Luraniec: 130 w woj. krakowskim, 
$11 \mathrm{w}$ tarnowskim; Lurans 0; 1 - Luranz w woj. bielskim; Lurańc 0; po 1 Lurenc w woj. bielskim i Lurentz w woj. lubelskim; Lureńczyk 0.

\section{Lawend}

SIW podaje 1 mężczyznę o imieniu Lawend w woj. krakowskim. SI nie notuje.

Od n. rośliny lawenda z derywacją wsteczną, gw. lewanda, o której szerzej pisałem w artykule o nazwisku Lewandowski [Breza, 1991, s. 255-258].

\section{Lawinia, Lawiniusz}

SIW podaje 26 kobiet o im. Lawinia i 1 mężczyznę noszącego im. Lawiniusz w woj. bielskim. SI, s. 166 podaje imię Lawinia z odpowiednikiem łacińskim Lavinia; Lavinia występuje w jęz. dun., fin., hiszp., hol., niem., port., rum., szw., węg. i wł.; Lavinie w cz. i fr.; Lavinija w ros., u Chorwatów, słwn. i ukr.; wariantywnie: Lavinia, Lavina i Lavena w ang.; Lavinija i Lonja w błr.; Lavinija, Lonča i Nijka w błg.; Lavinija i Lavinja w mac.; Lavinia i Lavinija w nowogr.; w wielu językach brak, np. obu łuż., nor. i słow., brak też formy męskiej, nienotowane w okresie staropolskim (SSNO).

Z wyzyskiwanych przeze mnie opracowań uwzględnia jedynie KNI, s. 190 z imieninami 14 IV. Według mitologii (zob. MEKSA I, s. 526; SMGiR, s. 204-205) Lawinia była córką króla Latynusa i żoną Eneasza, który założone przez siebie miasto w Lacjum nazwał na cześć Lawinii - Lavinium. SMGiR, s. 204-205 podaje, że w micie czysto greckim Lawinia jest córką kapłana Aniosa i, jako wieszczka, towarzyszką Eneasza w podróży na zachód. Jej imię odnoszą do gr. oinos 'wino', rdzenia widocznego w łac. vinum, niem. Wein, ang. wine, pol. wino, a więc bliskim (przynajmniej brzmieniowo) do Anios; a ciekawe, że trzy córki Aniosa określane były jako Oinotrófoi 'uprawiające winnicę'. Forma męska od Lavinium określająca jego mieszkańca to po łacinie Lavinius, z czego regularne polskie Lawiniusz. Liczne są przysłowia o winie, pamięć podsuwa mi: „In vino veritas” 'W winie prawda' (z dodatkiem: „a w wódce diabeł”, zbeletryzowane przez Adama Mickiewicza w balladzie Pani Twardowska); niem.: Die Frendschaft, die der Wein gemach, dauert nur, wie der Wein, eine Nacht 'Przyjaźń zrodzona przy winie, trwa, tak jak wino, tylko jedną noc".

\section{Lolek, Lolko, Lolo}

SIW podaje 13 mężczyzn o im. Lolek: po 3 w woj. katowickim i szczecińskim, po $2 \mathrm{w}$ białostockim i krakowskim, po $1 \mathrm{w}$ ciechanowskim, częstochowskim i radomskim; 1 -Lolko w woj. lubelskim, 1 -Lolo w woj. szczecińskim; 2 - Loliusz w woj. białostockim.

To zdrobnione, deminutywne lub spieszczone, hipokorystyczne formy imienia Karol, powstałe w języku dzieci, którym łatwiej wymówić spółgłoskę $l$ niż $r$, nadto 
wpływ na ukształtowanie się omawianych form miał także proces asymilacji, czyli upodobnienia. Przypomnieć warto, że na młodego Karola Wojtyłę też mówiono Lolek < Karolek. Postać Lolko utworzona została obocznym formantem -ko od podstawowego - $k$-, a Lolo wskutek derywacji wstecznej od Lolko; Loliusz jest formą analogiczną do imion łac. typu Aureliusz < łac. Aurelius.

Lenard, Lenardo, Lenart, Lenchard, Lennar, Lennart, Leonard i podobne SIW podaje 8 osób o im. Lenard: po 1 w woj. chełmskim, konińskim, poznańskim, przemyskim, piotrkowskim, rzeszowskim, suwalskim i włocławskim; $5-\mathrm{Le}$ narda: $2 \mathrm{w}$ woj. warszawskim, po $1 \mathrm{w}$ białostockim, katowickim i kieleckim, 1 - Lenardo w woj. bydgoskim; 1 - Lenart w woj. krakowskim, 1 - Lenarta w woj. lubelskim; 1 - Lenchard w woj. katowickim; 2 -Lennard: po $1 \mathrm{w}$ woj. katowickim i wrocławskim; 2 -Lennart: po $1 \mathrm{w}$ woj. jeleniogórskim i krakowskim; 12712 -Leonard; 7459 - Leonarda; 7 - Leonardo: po $1 \mathrm{w}$ woj. bielskim, częstochowskim, gdańskim, katowickim, olsztyńskim, opolskim, poznańskim; 3 - Leonardy: $2 \mathrm{w}$ woj. suwalskim, $1 \mathrm{w}$ gdańskim; 1 - Leonart w woj. warszawskim.

SI, s. 167-168 podaje imiona: męskie Leonard i żeńskie Leonarda z łacińskimi odpowiednikami Leonardus i Leonarda / Leonardis; Leonard występuje w jęz. błr., ros., rum. i ukr.; Lèanard w błg.; Léonard we fr., Leonardo w hiszp. i port.; Leonards w łot., Leōnardos w nowogr.; Lenart w słwn.; wariantywnie: Leonard, Leonerd, Lennard w ang.; Leonard, Lenard w cz. i słow.; Lennard, Leonard $\mathrm{w}$ dun.; Lenni, Lennart w fin.; Leonhard, Leonard, Leonardus, Leendert, Lennart, Lennart, Lindert w hol.; Leonardas, Lenardas w lit.; Leonard, Leonhard w obu łużyckich; Leonard, Leonhard w mac.; Leonhard, Lenard, Lienhard, Linnart w niem.; Lennart, Leonard w nor.; Leonard, Leonardo, Lenard, Lenardo u Chorwatów; Lennart, Leonard w szw.; Lénárd, Lénárt, Leonárd w węg.; Leonardo (por. Leonardo da Vinci), Lieonardo we wł. Formy żeńskie pomijam.

Podstawowe imię Leonard jest hybrydą grecko-germańską: w I członie występuje gr. rzeczownik léōn, w D. léont-os o podstawowym znaczeniu 'lew' (por. też łac. leo, -onis 'lew'), a w II - staro-wysoko-niem. przymiotnik hart = nowo-wysoko-niem. hard 'silny, mocny', zatem całe imię podlega wykładni 'silny jak lew', częstej w imionach, por. np. Bernard < Bernhard 'silny jak niedźwiedź', Eberhard 'silny jak dzik'. W staropolszczyźnie notowany m.in. jako Lenart lub Lenard od r. 1163 na Mazowszu, w Wielkopolsce, Małopolsce, na Kresach Południowo-Wschodnich, brak jedynie na Pomorzu (Mal III, s. 269); Lenard / Lenart to forma skrócona (pochodną patronimiczną por. u pisarza Teofila Lenartowicza); Leonardy to spolszczona forma D. derywacji fleksyjnej w jęz. łacińskim typu 
Joannes, filius Leonardi 'Jan, syn Leonarda'. Wiele postaci to po prostu błędy urzędnika stanu cywilnego, usankcjonowane urzędową pieczęcią.

\section{Leosław, Leosława}

SIW notuje 5 mężczyzn o imieniu Leostaw: 2 w woj. kaliskim, po 1 w radomskim, sieradzkim i szczecińskim; 1 kobietę noszącą imię Leosława w woj. konińskim.

Imię nigdzie nienotowane, utworzone zostało na wzór słowiańskich imion dwuczłonowych od imienia grecko-łacińskiego Leon z II członem -sław, por. Janisław, Tomisław.

\section{ROZWIAZZANIA SKRÓTÓW}

Abram - Abramowiczówna Zofia, red., 1958-1965, Słownik grecko-polski, t. I-IV, Warszawa.

BNOT - Tronina Antoni, Walewski Piotr, 2009, Biblijne nazwy osobowe i topograficzne, Słownik etymologiczny, Częstochowa.

DF - Koнlheim Rosa, Kohlheim Volker, 2000, Familiennamen. Herkunft und Bedeutung, Mannheim. Dudenverlag.

Go - Gottschald Max, 1954, Deutsche Namenkunde, 3. Auflage, Berlin.

IC - CAJAnto Iiro, 1965, The Latin Cognomina, Helsingfors, Helsinki.

Jougan - Ks. Jougan Alojzy, 1958, Słownik kościelny łacińsko-polski, wyd. 3, Poznań.

KIS - Ks. Fros Henryk SJ, SowA Franciszek, 1997-2007, Księga imion i świętych, t. I-VI, Kraków.

Knap - Knappová Milena, 1978, Jak se bude jmenovat?, Praha.

KNI - BubaK Józef, 1993, Księga naszych imion, Wrocław.

$\mathrm{Kr}-$ Kruczkiewicz Bronisław, red., 1925, Słownik łacińsko-polski do użytku szkół średnich, wyd. 2, Lwów - Warszawa.

KVNB - Naumann Horst, Schlimpert Gerhard, Schultheis Johannes, 1980, Das kleine Vornamenbuch, 3. Auflage, Leipzig.

Majtan - Majtán Milan, PovAžAJ Matej, 1985, Meno pre naše diet’a, Obzor, Bratislava.

Mal III - MALEC Maria, 1994, Imiona chrześcijańskie w średniowiecznej Polsce, Kraków.

MEKSA - Mała encyklopedia kultury świata antycznego, 1958-1962, t. I, red. Gabriela Pianko, t. II, red. Zdzisław Piszczek, Warszawa.

PrSB - Grabner-Haider Anton, red., 1994, Praktyczny słownik biblijny, Warszawa. 
SEMot - CieŚlikowa Aleksandra, Malec Maria, Rymut Kazimierz, red., 1995-2002, Słownik etymologiczno-motywacyjny staropolskich nazw osobowych, cz. I-VII, Kraków.

SIW - Rymut Kazimierz, red., 1995, Słownik imion współcześnie w Polsce używanych, Kraków.

SKA - WINNICZUK Lidia, red., 1986, Słownik kultury antycznej, wyd. IV, Warszawa.

SMGiR - Grimal Pierre, 1987, Słownik mitologii greckiej i rzymskiej, Wrocław.

SNW - Rymut Kazimierz, red., 1990-1992, Słownik nazwisk współcześnie w Polsce używanych, t. I-X, Kraków.

SSNO - TASZYCKI Witold, MALEC Maria, red., 1965-1987, Słownik staropolskich nazw osobowych, t. I-VII, Wrocław.

Sych - Ks. Sychta Bernard, 1967-1976, Słownik gwar kaszubskich na tle kultury ludowej, t. I-VII, Wrocław.

Wyk - BubaK Józef, 1983, Wykaz imion używanych w Polskiej Rzeczypospolitej Ludowej, ,Język Polski”, 63, z. 1-2, s. 72-84.

\section{WYKAZ SKRÓTÓW NAZW JĘZYKÓW EUROPEJSKICH}

\begin{tabular}{|c|c|c|c|}
\hline ang. & - angielski & mac. & - macedońsk \\
\hline blg. & - bułgarski & niem. & - niemiecki \\
\hline & - białoruski & nor. & - norweski \\
\hline & - czeski & nowogr. & - nowogrecki \\
\hline lnołuż. - & - dolnołużycki & port. & - portugalski \\
\hline an. & - duński & ros. & - rosyjski \\
\hline & - estoński & rum. & - rumuński \\
\hline & - fiński & słow. & - słowacki \\
\hline & - francuski & słwn. & - słoweński \\
\hline rnołuż. - & - górnołużycki & sZW. & - szwedzki \\
\hline szp. & - hiszpański & ukr. & - ukraiński \\
\hline- & - holenderski & węg. & - węgierski \\
\hline & - litewski & wł. & - włoski \\
\hline & - łotewski & & \\
\hline
\end{tabular}

BIBLIOGRAFIA

BREZA Edward, Zalety imionami ludzi, Gdańsk 2014.

BrezA Edward, Polskie nazwisko Lewandowski, Prace Filologiczne XXXVI, 1991, s. $255-258$ 